\title{
The Social Organization of the Provisioned Japanese Monkey Troops Which Have Extraordinary Large Population Sizes
}

\author{
Akio MORI \\ Primate Research Institute, Kyoto University
}

\begin{abstract}
Two Provisioned Japanese monkey troops, the Takasakiyama A and $\mathrm{B}$ troops have extraordinary large population sizes, consisting of about 1000 and 300 monkeys respectively. Dominance tests were conducted among identified adult females of the Takasakiyama A and B troops. Because many pairs showed indefinite dominance relationships and the linear dominance rank order was not observed, individuals were given "dominance rank by ratio". Information of the dominance tests was obtained about two other troops. Indefiniteness of the cominance relationships increased quantitatively and qualitatively with the increase of the population size of the troop. The discrepancy up to now in the reports about the process of troop divisions is related to the population size of the troops and the occurence of indefinite dominance pairs.
\end{abstract}

\section{INTRODUCTION}

The Takasakiyama A troop, a Japanese monkey troop, consists of about 1000 monkeys. The population size of the troop is nearly ten times or more larger than that of ordinary sized troops. It is doubtful that the amount of social interactions and communications among troop members is sufficient to establish inter-individual relationships, the social network, and to maintain the integrity of the troop. Thus, inter-individual relationships which are of vital importance for the integrity of the troops of ordinary population sizes, may have small roles in the mechanisms maintaining the integrity of a troop having an extraordinary large population size. Dominance rank order is one of the mechanisms maintaining the integrity of troops. It is based on identification of each other by troop members, and is the summing-up of all the dominant-subordinate relationships. Thus, it is dobutful that dominance rank order exists among the members of the Takasakiyama A troop, especially among adult females which consists of many members, as it exists in the troops of ordinary population sizes.

It is of much interest what kind of role adult females and the dominance rank order among them have in the mechanisms of maintaining the integrity of a troop. In this report the dominance rank orders were investigated among adult females of four troops of the Japanese monkey, having different sizes of population, on Takasakiyama mountain. It is shown that the difference of dominance rank order 
among adult females is related to the difference of the population sizes of troops. The mechanisms of maintaining the integrity of a troop are discussed in relation to the role of the dominance rank order among adult females.

\section{SUBJECTS AND METHODS}

The author investigated dominant and subordinate relationships among adult females of the Takasakiyama $A$ troop and the $\mathrm{B}$ troop. Besides this data, information of the dominant-subordinate relationships among adult females in two other Takasakiyama troops were obtained.

The population size of the Takasakiyama troop was first estimated to be 170 by ITANI in 1950 (ItANI, 1954). The troop was first provisioned in 1952. The population size was 220 in 1953 (ITANI, 1954). The population size has increased rapidly since the beginning of the provisioning of the troop and the division of the troop followed as a result. The first division occurred in 1953 when the troop size was about 650 (Sugiyama, 1960). The main and the branch troops were called $A$ and $\mathrm{B}$ troops, respectively. When the population size of the A troop was 590, it was further divided into two troops, $A$, the main and $C$, the branch troop on the second division (KANO, 1964). The branch D troop* came out of the A troop whose population size was about 1000 (NisHIMURA, 1973). The troop sizes of the A, B and C troops in September 1973, just before this study, were 983, 292 and 260,

*The D troop was captured shortly after the troop division. respectively (Sugiyama, Nishimura, OHSAWA and MASUI, in press). The study periods were from November 1973 until February 1974, "the study in winter", and in June 1974, "the study in June". The mating season was from December until March. The author identified individually 153 and 45 adult females out of total 308 and 85 adult females (SUGIyama, Nishimura, OHsawa and Masui, in press) in the $\mathrm{A}$ and in the $\mathrm{B}$ troops, respectively.

The test of diciding the dominant individual between each pair of monkeys was conducted primarily through " peanut tests" (ITANI, 1954). A peanut was placed between two monkeys or a peanut on the palm of the experimenter was shown between two monkeys and handed to them. The one that took the peanut was decided to be dominant over the other. The experimenter tried to eliminate the effect of a third individual, especially of an adult male or an adult female, on a test - the dependent rank (KAWAI, 1958). Aggressive behavior or submissive facial expressions at being approached by a dominant individual, also gave some information on dominant individuals. In order to obtain some information about blood relationships, all the cases of grooming relationships observed were record ed.

\section{RESULTS}

1. Dominance tests among adult females of the Takasakiyama A troop

Dominance tests were conducted among adult females of the Takasa kiyama $\mathrm{A}$ 
troop. Definite dominant and subordinate relationships were observed in many tests. However, unlike the troops of ordinary sizes, it was impossible in many tested pairs to determine which one of the tested individuals was dominant. Both of the individuals tested tried to reach out to the peanuts and alternatively took the peanuts given repeatedly in such cases. In these cases both of the tested individuals seemed to behave hesitantly to one another. These cases were called "even relationships". In some pairs, each dominance test showed a clear dominance relationship, but the dominant individual estimated changed from test to test.

Hereafter, an "indefinite pair" stands for the pair which showed two kinds of results of tests; (1) the dominant individual alternated from test to test, (2) over half of the tests between a pair of individuals showed the even relationship.

The adult females that were tested with over twenty individuals among identified adult females amounted to 120 . As many cases of triangular dominant-subordinate relationship among three individuals-none of them were dominant over the other two-were found, it proved to be quite impossible to arrange all of the identified adult females linearly from dominant to subordinate individuals. Thus, these 120 adult females were arranged according to higher to lower "dominance rank by ratio" (appendix I). Then, thus arranged 120 individuals were divided into three classes, upper, middle and lower class, each consisting of 40 individuals. Then, individuals whose tests within each class was scarce, were excluded. Then, members of the upper, middle and lower class were reduced to 39,39 and 32 individuals. Individuals were rearranged according to higher to lower dominance rank by ratio within each class, and the table of dominance tests was made for each class. The resultant arrangement of 110 adult females is named to be "dominance rank order by ratio" and all of the 110 adult females were given a common "dominance rank by ratio". Thus, individuals listed on the tables have dominance rank by ratio, $1 \mathrm{st}-39$ th in the upper class, 40 th-78th in the middle and $79-110$ th in the lower class.

As it was very difficult to conduct dominance tests among females of lower rank, without any effect by other individuals, the frequencies of tests among them were relatively low. Though data were not sufficient among females of lower class, individuals could be arranged in accordance with dominance rank order by ratio. The indefiniteness of dominance rank order among them could be grasped qualitatively, but not quantitatively. As all of the three tables of dominance tests within each class indicated the same tendency, the tables of dominance tests only in the upper class is presented here (Table 1). Many pairs indicated indefinite dominantsubordinate relationships, differing much from earlier reports, in ordinary sized troops, which stated definite dominance rank order being based on blood relationships (Kawamura, 1958; Koyama, 1967). In order to grasp the degree of indefiniteness of dominance relationships, the ratio 
Table 1. Dominance tests among high ranking females of the Takasakiyama A troop in the winter study period.

Individuals were arranged according to higher to lower dominance rank by ratio in the left column and in the upper row. The mark, $O$, in each cell indicates that the corresponding individual in the left column was dominant over that in the upper row in over half of the tested cases. The mark, $x$, indicates that the individual in the column was subordinate to that in the row. The cell where the mark $x$ is added over the mark $\bigcirc$ indicates that the dominant individual changed from test to test between the individual in the column and that in the row. The mark, =, indicates that the even relationship was observed in half and over half of th tested cases.

\begin{tabular}{|c|c|c|c|c|c|c|c|c|c|c|c|c|c|c|c|c|c|c|c|c|c|c|c|c|c|c|c|c|c|c|c|}
\hline & & & 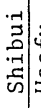 & & & $\mid$ & & & $\frac{\pi}{\tilde{Z}}$ & 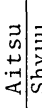 & & & & 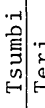 & & & $\mid \begin{array}{c}-\pi \\
\tilde{u} \\
0 \\
:\end{array}$ & & & & & 童 & 莺 & & & . & & & 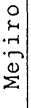 & & \\
\hline 1. Gara & 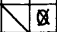 & 0 & 0 & 0.0 & 0 & 00 & 0.0 & 0 & 0 & \begin{tabular}{l|l}
0 & 0 \\
\end{tabular} & 00 & 0 & 0 & & 00 & 0 & & 0 & 0 & 50 & & & 0 & 0 & & 0 & 00 & & 0 & & \\
\hline 2. Ikari & & $\otimes$ & $\mathrm{x}$ & 00 & 0 & 00 & 0 & 0 & 0 & 0.0 & \begin{tabular}{l|l}
0 & 0 \\
\end{tabular} & 0 & 0 & 0.0 & 00 & 0 & 0 & $\otimes$ & & 0.0 & 0 & 0 & 0 & D & 0 & $=$ & 00 & 0 & 0 & 0 & \\
\hline 3. Nyun & & & 0 & 0 & 0 & $\$ 1$ & $\otimes$ & 0 & 0 & 0 & 0 & 0 & $\otimes$ & 00 & 00 & & & 0 & 06 & 0.0 & & 0 & 0 & 0 & 0 & $\otimes$ & 00 & & 0 & 0 & \\
\hline 4. Shibui & & & & $\otimes 0$ & 0 & 0 & & 0 & 0 & 00 & $\begin{array}{ll}0 & 0 \\
\end{array}$ & 0 & $\otimes$ & 0 & $0=$ & 0 & 0 & 0 & & 00 & & \begin{tabular}{|l|l|}
0 \\
\end{tabular} & 0 & & $\otimes$ & & & 0 & 0 & 0 & \\
\hline 5. Haafu & & & & 10 & 0 & $\otimes$ & & & $\otimes$ & $\otimes C$ & 0 & 0 & & \begin{tabular}{l|l}
0 & 0 \\
\end{tabular} & 0 & & 0 & $\otimes$ & 0 & $\times 0$ & 0 & 0 & & $\begin{array}{ll}0 & 0 \\
\end{array}$ & & & 0 & & 0 & & \\
\hline 6. Game & & & & & 車 & $\Phi=$ & $=$ & 0 & $=$ & 0,0 & $\begin{array}{ll}0 & 0 \\
\end{array}$ & 0 & 0 & 0 & & 0 & 0 & 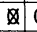 & 0 & Q 0 & & & \begin{tabular}{l|l}
0 & 0 \\
\end{tabular} & \begin{tabular}{l|l}
0 & 0 \\
\end{tabular} & 0 & 0 & 00 & 0 & & 0 & \\
\hline 7. Ito & & & & & & 00 & 0 & $\otimes$ & $x$ & $x$ & 0 & 0 & 0 & 0 & $\otimes$ & $=$ & 0 & 0 & & \begin{tabular}{l|l}
0 & 0 \\
\end{tabular} & 0 & 0 & \begin{tabular}{l|l}
0 & 0 \\
\end{tabular} & \begin{tabular}{l|l}
0 & 0 \\
\end{tabular} & 0 & $\otimes$ & 00 & 0 & 0 & 0 & \\
\hline 8. Harumi & & & & & & 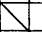 & 0 & 0 & $\otimes$ & $=$ & $0 x$ & $\otimes$ & 0 & 0 & 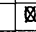 & & & W & & 0.0 & & 0 & $\begin{array}{ll}0 & 0 \\
\end{array}$ & 00 & 0 & 0 & 0 & & 0 & & \\
\hline 9. Nigir & & & & & & & & 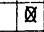 & & $\mathrm{x}$ & & $=$ & & 0 & 0 & $\bar{x}$ & & & 0 & 0 & & $=$ & \begin{tabular}{l|l}
0 & 0 \\
\end{tabular} & $\begin{array}{ll}0 & 0 \\
\end{array}$ & 0 & 0 & & & 0 & 0 & \\
\hline 10. Fusa & & & & & & & & & $x$ & $\mathrm{x}$ & 0 & 0 & 0 & 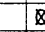 & $\theta$ & & 0 & 0 & 0 & 0.0 & & 0 & $=$ & $=0$ & & & & 0 & & & \\
\hline 11. Kirare & & & & & & & & & $x$ & $\otimes$ & 0 & $\otimes$ & 0 & 00 & $5 x$ & $x$ & 0 & 0 & 0 & $\begin{array}{ll}0 & 0 \\
\end{array}$ & & 0 & $\begin{array}{lll}0 & 0 \\
\end{array}$ & $\begin{array}{ll}0 & 0 \\
\end{array}$ & 0 & $\otimes$ & $\otimes 0$ & 0 & 0 & 0 & \\
\hline 12. Muda & & & & & & & & & & $0 x$ & $x \bar{x}$ & 0 & & 0 & 00 & & 0 & 0 & 01 & $\otimes$ & & $\otimes$ & 0 & 0 & $=$ & 0 & $x$ & & $=$ & 0 & \\
\hline 13. Aits & & & & & & & & & & $\mathrm{c}$ & 00 & 0 & $=$ & 0 & $0 x$ & & 0 & 0 & 0 & 00 & 0 & 0 & 00 & \begin{tabular}{l|l}
0 & 0 \\
\end{tabular} & $\otimes$ & $\mathrm{x}$ & 0,0 & 0 & & 0 & \\
\hline 14. Shyuu & & & & & & & & & & & 0 & 四 & & $\otimes$ & $x$ & $=$ & $\otimes$ & $\otimes$ & 0 & 0 & 0 & 0 & 0 & \begin{tabular}{l|l}
0 & 0 \\
\end{tabular} & 0 & & 0 & & 0 & 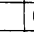 & \\
\hline 15. Tsuno & & & & & & & & & & & & $\otimes$ & 0 & & 0 & $\bar{x}$ & 0 & 0 & 0 & 0 & & 0 & 0 & 0 & 0 & $\mathrm{x}$ & c & 0 & 0 & 0 & \\
\hline 16. Nina & & & & & & & & & & & & & 0 & $0 x$ & $x \times$ & 0 & 0 & $\otimes$ & 0 & $\begin{array}{ll}0 & 0\end{array}$ & 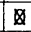 & 0 & 00 & $\begin{array}{l}0 \\
0\end{array}$ & 0 & 0 & \begin{tabular}{l|l}
0 & 0 \\
\end{tabular} & 0 & & 0 & \\
\hline 17. Shyaku & & & & & & & & & & & & & & $0 \otimes$ & 00 & & 0 & 0 & 0 & 00 & & & c & $0=$ & 0 & 0 & 0 & & 0 & & \\
\hline 18. Tsumbi & & & & & & & & & & & & & & & & & 0 & 0 & $x$ & $0 \otimes$ & 0 & 0 & $\Delta$ & 0 & 0 & 0 & 00 & 0 & & 0 & \\
\hline 19. Teri & & & & & & & & & & & & & & & 0 & & 0 & 0 & 0 & 00 & 0 & 0 & & $x$ & 0 & & 0 & & 0 & & \\
\hline 20. Ten & & & & & & & & & & & & & & & & 0 & $\otimes$ & $x$ & 0 & $\otimes 0$ & & & & \begin{tabular}{l|l}
$x$ \\
\end{tabular} & $\otimes$ & $\otimes$ & 0 & & & 0 & \\
\hline 21. Paru & & & & & & & & & & & & & & & & & 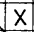 & $x$ & 0 & 00 & & & & & & & & & & 1 & \\
\hline 22. Kechi & & & & & & & & & & & & & & & & & & 0 & $\mathrm{x}$ & 00 & $x$ & 0 & & 0 & 0 & 0 & 0 & & $\otimes$ & 0 & \\
\hline 23. Egoni & & & & & & & & & & & & & & & & & & & $\otimes$ & $x \mid x$ & $=$ & 0 & & 0 & $\otimes$ & $\otimes$ & 00 & 0 & 0 & & \\
\hline 24. Magari & & & & & & & & & & & & & & & & & & & & 00 & $x$ & 0 & $x=$ & $=0$ & 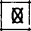 & 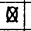 & $\otimes$ & 0 & 0 & 0 & \\
\hline 25. Burar & & & & & & & & & & & & & & & & & & & & $\otimes$ & $\otimes$ & $\otimes$ & 00 & $\begin{array}{ll}0 & 0 \\
\end{array}$ & Q & $\otimes$ & $\times 0$ & 0 & $\otimes$ & 0 & \\
\hline 26. Mur & & & & & & & & & & & & & & & & & & & & & 0 & $x$ & $\mathrm{x} 0$ & $0=$ & & $凶$ & 00 & 0 & 0 & $\otimes$ & \\
\hline 27. Masa & & & & & & & & & & & & & & & & & & & & & & $\mathrm{x}$ & & $\bar{x}$ & 0 & & $x$ & & $x$ & T & \\
\hline 28. Kyuu & & & & & & & & & & & & & & & & & & & & & & & & $\begin{array}{ll}\times 0 \\
\end{array}$ & $x$ & $\otimes$ & 00 & $\otimes$ & $\otimes$ & $\otimes$ & \\
\hline 29. Kin & & & & & & & & & & & & & & & & & & & & & & & $=$ & $=$ & & 0 & & & & 0 & \\
\hline $30 . \mathrm{M}$ & & & & & & & & & & & & & & & & & & & & & & & & & $=$ & & $x \times$ & & $\otimes$ & t & \\
\hline 31. Kesa & & & & & & & & & & & & & & & & & & & & & & & & & $x$ & 0 & $0 . x$ & 0 & $\otimes$ & & \\
\hline 32. Shita & & & & & & & & & & & & & & & & & & & & & & & & & & $\otimes$ & 0 & $\otimes$ & $\otimes$ & 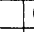 & \\
\hline 33. Suma & & & & & & & & & & & & & & & & & & & & & & & & & & & $\otimes \otimes$ & $x$ & & & \\
\hline 34. Iro & & & & & & & & & & & & & & & & & & & & & & & & & & & 8 & $\bar{x}$ & $x$ & $\mathrm{x}$ & \\
\hline 35. Fuji & & & & & & & & & & & & & & & & & & & & & & & & & & & & $\mathbb{Q}$ & $=$ & 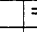 & \\
\hline 36. Pochi & & & & & & & & & & & & & & & & & & & & & & & & & & & & & & & \\
\hline 37. Mejiro & & & & & & & & & & & & & & & & & & & & & & & & & & & & & & & \\
\hline 38. Tsuru & & & & & & & & & & & & & & & & & & & & & & & & & & & & & & 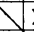 & \\
\hline 39. Osore & & & & & & & & & & & & & & & & & & & & & & & & & & & & & & & \\
\hline
\end{tabular}


Table 2. The ratio of pairs having unstable dominant-subordinate relationship to total pairs.

\begin{tabular}{ccccc}
\hline troop & $\begin{array}{c}\text { observation } \\
\text { period }\end{array}$ & $\begin{array}{c}\text { troop } \\
\text { size }\end{array}$ & $\begin{array}{c}\text { unstable pair } \\
\text { total pair }\end{array}$ & $\begin{array}{c}\text { identified ad. } \$ \\
\text { troop size }\end{array}$ \\
\hline A & 1973 & 990 & $\begin{array}{c}0.19 \\
\text { (upper class) } \\
0.22\end{array}$ & 0.12 \\
B & 1973 & 295 & 0.08 & \\
D & 1967 & 74 & 0.025 & 0.15 \\
$\begin{array}{c}\text { Takasakiyama } \\
\text { troop }\end{array}$ & 1955 & 358 & 0.06 & 0.35 \\
\hline
\end{tabular}

of indefinite pairs to the total pairs tested is calculated (Table 2). The ratios were 19.0 and $22.3 \%$ for the upper and the middle class respectively.

Much attention should be paid to the closeness of dominance rank by ratio between two individuals whose dominance relation was indefinite, because the first question that arises is whether the dominance rank system becomes, if it does, unstable first only between those individuals that have similar rank order or also between those of quite different rank order. The difference of dominance rank by ratio of each pair is represented by the distance from the diagonal line to each cell in the dominance table. The cells of pairs each of which have the same difference of rank between its members are lined in parallel with the diagonal line in the table of dominance rank by ratio. Pairs of indefinite dominance relationships were not only found in cells which were close to the diagonal line of the dominance table but were also found in cells which were quite apart from the diagonal line, indicating that the domi- nance relationship was established firmly neither in pairs whose members have similar dominance rank by ratio nor in pairs whose members have quite differing dominance rank by ratio.

Quantitative analysis is conducted on the difference of rank between individuals of pairs which showed indefinite dominance relationships. Pairs of indefinite dominance relationships were selected from the dominance table. The numbers of the indefinite pairs for each difference of dominance rank were counted. The relative frequency distribution pattern of the numbers of pairs to the differences of rank by ratio was indicated for the upper and the middle class (Fig. 1-a, b). In order to obtain a basis for the comparison of the relative frequency distribution patterns, the random distribution pattern of differences of rank by ratio is calculated in the hypothesis that indefinite dominance pairs do not have any correlation with the difference of dominance rank by ratio. On this hypothesis, the cells of indefinite dominance pairs will be distributed all over the dominance table. 


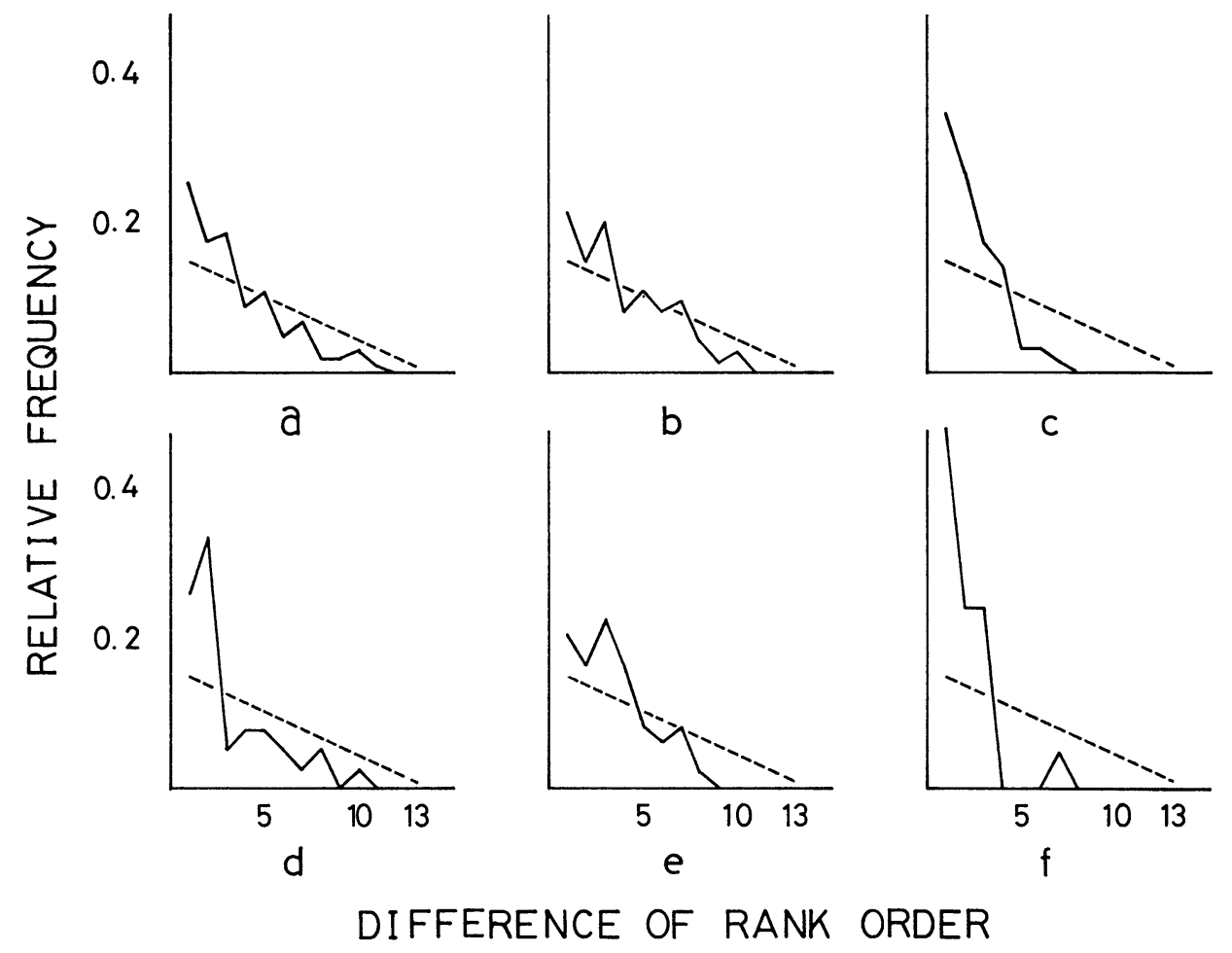

Fig. 1. Relative frequency distribution of the differences of ranking order within pairs which have unstable dominance relationships.

(a) The upper class of the Takasakiyama A troop in winter. (b) The middle class of the Takasakiyama A troop in winter. (c) The Takasakiyama B troop in winter. (d) The upper class of the Takasakiyama A troop in June. (e) The Takasakiyama B troop in June. (f) The Takasakiyama troop in 1955.

Solid lines indicate observed frequency distributions and the broken lines indicate the expected frequency for no correlation with the difference of rank. The numbers in the abscissa indicate the differences of dominance rank by ratio, and the difference of rank was grouped by three ranks; when the numbers in the abscissa are $1,2,3,4, \cdots \cdots 13$, the differences of rank are $(1 \sim 3),(4 \sim 6),(7 \sim 9),(10 \sim 12), \cdots \cdots(37 \sim 39)$.

Thus, the random relative distribution pattern is the relative distribution pattern of the differences of rank of all possible pairs. The probability distribution pattern of the differences of rank is calculated (Appendix 2 (a)) (Fig. 1).

Looking over the figure, the pairs of indefinite dominance relationships were found in pairs, each of which have a large difference of dominance rank by ratio between its members. This result is remarkable for the question of whether the dominance rank system becomes unstable only between individuals that have similar or also between quite different dominance rank by ratio. Though pairs 
of individuals of quite differing dominance rank by ratio showed indefinite dominance relationships, a slight tendency was observed in the figure, that the smaller the difference of dominance rank the more the indefinite pairs.

There were many factors which caused the indefinite relationships, such as the large population size of the troop. There is a report that young individuals, under 6 years or so, sometimes do not follow the principal of determination of dominance relationships among adult femalesKAWAMURA's hypothesis (Koyama, 1967). Most of the 110 monkeys selected and listed on the dominance tables were 7 years old or more and those individuals that were estimated to be under 6 years old were 7 at maximum and might be 4 in fact. This low ratio of younger adult females is attributed to the method of the author's identification of individuals; most of the identified individuals were 7 years old or more.

2. Dominance tests among adult females of the Takasakiyama B troop.

In order to obtain a comparable data of dominance rank system in a smaller sized troop than the extraordinary large sized Takasakiyama A troop, dominance tests were conducted among adult females (45 identified females) of the Takasakiyama B troop consisting of 292 monkeys. It proved to be impossible to arrange all the identified adult females of the B troop linearly in accordance with dominance order just as it was in the $A$ troop. Individuals were arranged in accordance with higher to lower dominance rank by ratio and the dominance table of the $B$ troop was formed just as the dominance table of the A troop had been done (Table 3 ). The relative frequency distribution pattern of the differences of rank by ratio between individuals of indefinite dominance relationship was figured for the 1st to 40th adult females (Fig. 1-c). The ratio of indefinite pairs to the total pairs tested was 8.0 which was fairly lower than 19.0 and $22.3 \%$ of the upper and middle class of the A troop (Table 2). The tendency toward higher the ratio of indefinite pairs the smaller the differences of dominance rank by ratio, was much more remarkalbe in the $B$ troop than in the A troop.

There is a problem in comparing the dominance tables-especially the differences of dominance rank by ratio-of the $A$ and the $B$ troop on the same basis, because a tendency which is found among the selected and identified individuals does not necessarily represent the tendency which may exist among all the adult females. When all of the adult females are postulated to be arranged linearly in accordance with dominance rank order, the identified individuals will be distributed at intervals among all the arranged adult females. As the ratio of identified individuals for the $\mathrm{A}$ and the $\mathrm{B}$ troops were nearly equal, 0.11 and 0.15 (Table 2 ), the numbers of unidentified monkeys between two adjoining identified individuals is much more on average in the $A$ troop than in the $B$ troop in each of the postulated dominance tables among all of the adult females of the $A$ and the $B$ 
Table 3. Dominance tests among adult females of the Takasakiyama B troop in the winter study period.

$\bigcirc, \times,=:$ see the notation in Table 1 .

\begin{tabular}{|c|c|c|c|c|c|c|c|c|c|c|c|c|c|c|c|c|c|c|c|c|c|c|c|c|c|c|c|c|c|c|c|c|c|c|}
\hline & & & & & & & & & & 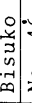 & & & & & & & & & & & & 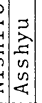 & & & & 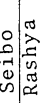 & & & 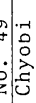 & & & & & \\
\hline 1. Tsurime & & 20 & & 10 & 0 & & 00 & & 0 & 0 & 0 & 50 & 0 & 00 & 00 & 0 & 00 & 00 & 0 & $0 \mathrm{C}$ & 00 & 0 & 00 & 0 & 0 & 00 & 0 & & 50 & 0 & & 0 & 0 & 0 \\
\hline 2. Bego & & & & 0 & 0 & 0 & 0 & 0 & 0 & 06 & $0 \mathrm{c}$ & 50 & 0 & 00 & 50 & 0 & 0 & 0 & 0 & $0 \mathrm{c}$ & 00 & 0 & 00 & 0 & 0 & 00 & & 00 & 0 & & & 0 & 00 & 0 \\
\hline 3. Ts umuji & & & & 0 & $\otimes$ & 0 & $\Delta$ & 8 & 0 & 0 & 00 & 50 & 0 & 00 & 00 & 0 & $0: 0$ & 00 & 0 & 0 & 00 & 0 & 00 & 0 & 0 & $\begin{array}{lll}0 & 0 \\
\end{array}$ & 0 & 00 & 0 & 0 & 0 & & 00 & \\
\hline 4. Ats sum & & & & 0 & $x$ & $x$ & 0 & 18 & 0 & 0 . & $\times c$ & 5. & 0 & 00 & 0 & 0 & 010 & 0 & 0 & 0 & 0 & 0 & c & 0 & & $\begin{array}{ll}0 & 0 \\
\end{array}$ & 0 & 00 & 50 & 0 & \begin{tabular}{l|l}
0 \\
\end{tabular} & 0 & 00 & 0 \\
\hline 5. Koyul & & & & & $\otimes$ & 0 & c & 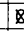 & 0 & 0 & 0 & 50 & 0 & 0 & 0 & & 00 & 00 & 0 & 0 & & 0 & 00 & 0 & & 00 & 0 & & & 0 & 0 & & 0 & \\
\hline 6. Ibo & & & & & & 0 & Q & $=$ & $\bar{x}$ & 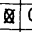 & 0.0 & 0 & 0 & $0 \otimes$ & 20 & 0 & & 00 & 0 & $0=$ & $=0$ & & 00 & 0 & 0 & 00 & 0 & 010 & 50 & 0 & 00 & 0 & $0 \longdiv { 0 }$ & 0 \\
\hline 7. Anzu & & & & & & & 18 & 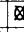 & & 0 & & $x$ & 0 & & 50 & 0 & 0,0 & 00 & 0 & 02 & $\begin{array}{l}x \\
\end{array}$ & 10 & $0 \mathrm{C}$ & 0 & 0 & 0.0 & 0 & & 00 & & & & & \\
\hline $8 . \mathrm{H}$ & & & & & & & 8 & & 0 & & 0 & 0 & 0 & $\otimes=$ & $=0$ & $\otimes$ & 010 & 00 & 0 & $\mathrm{x}$ & 0 & 0 & 0.0 & 0 & & 00 & 0 & 0 & & 0 & 0 & & 0 & 0 \\
\hline 9. Chyo & & & & & & & & & & $x$ & $\triangle 0$ & & $x$ & $\begin{array}{lll}0 & 0 \\
\end{array}$ & 0 & & 00 & 00 & 0 & 0 & 0 & 0 & 00 & 0 & 0 & 00 & 0 & & 510 & 0 & & & & 0 \\
\hline $10 . \mathrm{H}$ & & & & & & & & & $\otimes$ & 0 & 00 & 50 & Q & 00 & 50 & 0 & 0.0 & 00 & 0 & 0 & $0 \mid 0$ & 0 & 00 & 0 & & 00 & 0 & 0 & 0 & 0 & 0 & 0 & $0 \mathrm{C}$ & \\
\hline. & & & & & & & & & & 0 & $\otimes 0$ & 50 & 0 & 00 & 5 & 0 & 00 & 00 & & 0 & 0 & 0 & 00 & 0 & & 00 & 0 & & 0 & & & & 06 & \\
\hline$\therefore \mathrm{B}$ & & & & & & & & & & & $x$ & 5 & $x$ & 00 & $\otimes$ & 0 & 00 & 00 & 0 & 01 & $\times 0$ & 0 & 10 & 0 & 0 & \begin{tabular}{l|l}
0 & 0
\end{tabular} & 0 & \begin{tabular}{l|l}
0 & 0 \\
\end{tabular} & 50 & \begin{tabular}{l|}
0 \\
\end{tabular} & 0 & & \begin{tabular}{l|l} 
& 0 \\
\end{tabular} & 0 \\
\hline $3 . \mathrm{N}$ & & & & & & & & & & & & $8 x$ & 0 & & $5=$ & 0 & 00 & 00 & 0 & 07 & $\times 0$ & 0 & $0 \mathrm{C}$ & 0 & 0 & \begin{tabular}{l|l}
0 & 0 \\
\end{tabular} & & & & 0 & & & & 0 \\
\hline . $\mathrm{KC}$ & & & & & & & & & & & & 0 & 0 & $x$ & & & $0] 0$ & 00 & 0 & $\otimes$ & & & 00 & 0 & & 00 & 0 & 0 & 0 & 0 & 00 & & 0 c & 0 \\
\hline 15. Junia & & & & & & & & & & & & & & $\begin{array}{ll}x & 0 \\
\end{array}$ & & 0 & $0: x$ & $x \otimes$ & $\otimes$ & 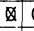 & $0=$ & & $0=$ & $\otimes$ & 0 & $\begin{array}{ll}0 & 0 \\
\end{array}$ & 0 & 0 & & 0 & 00 & 0 & 010 & 0 \\
\hline 5 & & & & & & & & & & & & & & $0=$ & $=0$ & 0 & 00 & 00 & 0 & 0 & $x$ & 0 & & 0 & & 0 & 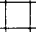 & 0 & 0 & & 0 & & 00 & 0 \\
\hline . $\mathrm{Mi}$ & & & & & & & & & & & & & & & \begin{tabular}{l|l}
$x$ \\
\end{tabular} & 0 & 00 & 00 & & 0 & 0 & $\otimes$ & $\begin{array}{ll}0 & 0 \\
\end{array}$ & 0 & 0 & 00 & 0 & 00 & to & 0 & 0 & & 0 & 0 \\
\hline . A & & & & & & & & & & & & & & & 0 & 0 & & 0 & & 0 & & 0 & & 0 & & 0 & 0 & 0 & 5 & 0 & & & $0 c$ & \\
\hline . $\mathrm{H}$ & & & & & & & & & & & & & & & & $x$ & & 0 & 0 & 01 & $\times 0$ & $x$ & 00 & 0 & 0 & \begin{tabular}{l|l}
0 & 0 \\
\end{tabular} & 0 & Q & 0 & 0 & 0 & 0 & $0 \mathrm{C}$ & 0 \\
\hline $20 . \mathrm{R}$ & & & & & & & & & & & & & & & & & & 50 & & 0 & & $=$ & & 0 & 0 & 00 & & & 0 & - & & 0 & & 0 \\
\hline.$Y$ & & & & & & & & & & & & & & & & & & $0 x$ & $\otimes$ & $x$ & 0 & & $0 x$ & & 0 & $0 x$ & 0 & $\begin{array}{l}x \\
x\end{array}$ & 0 & & 00 & & c & \\
\hline 5 & & & & & & & & & & & & & & & & & & $x$ & 0 & $\mathrm{x}$ & $x$ & & $0 \bar{x}$ & 0 & & 00 & 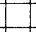 & 0 & 0 & & & 0 & 0 & 0 \\
\hline 3. $\mathrm{Al}$ & & & & & & & & & & & & & & & & & & & & ब & $0=$ & $=\otimes$ & 08 & $\otimes$ & 0 & 0 & 0 & 0 & 0 & 0 & 0 & & $0 \mathrm{C}$ & \\
\hline 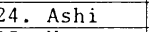 & & & & & & & & & & & & & & & & & & & & $x$ & & & $0 x$ & 0 & 0 & $\times 10$ & 0 & 0 & 0 & & 00 & & 00 & 0 \\
\hline $5 . Y$ & & & & & & & & & & & & & & & & & & & & & $x \times$ & $x$ & 0.0 & $\otimes$ & 0 & \begin{tabular}{l|l}
0 & 0 \\
\end{tabular} & 0 & & 0 & & 0 & & 0 & 0 \\
\hline. $\mathrm{H}$ & & & & & & & & & & & & & & & & & & & & & Q & & & & & $=$ & 0 & $x$ & X & & 0 & & 010 & \\
\hline $\mathrm{N}$ & & & & & & & & & & & & & & & & & & & & & & & $x$ & Q & 0 & \begin{tabular}{l|l}
0 & 0 \\
\end{tabular} & 0 & 0 & 0 & 0 & 0 & 0 & 00 & 0 \\
\hline A & & & & & & & & & & & & & & & & & & & & & & & & & 0 & 4 & & 0 & 50 & & & & 0 & \\
\hline I & & & & & & & & & & & & & & & & & & & & & & & & 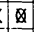 & 0 & $x$ & ه & & 50 & 0 & 0,0 & & 00 & 0 \\
\hline . $\mathrm{T}$ & & & & & & & & & & & & & & & & & & & & & & & & $\otimes$ & & 00 & $=$ & 0 & 0 & 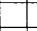 & 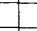 & 0 & 10 & \\
\hline 0 & & & & & & & & & & & & & & & & & & & & & & & & & 0 & $0 \otimes$ & $\otimes$ & 00 & 5 & 0 & & 0 & $0 / 0$ & 0 \\
\hline$\therefore \mathrm{Ka}$ & & & & & & & & & & & & & & & & & & & & & & & & & & $x \times$ & $x$ & 0 & 0 & & 00 & & 010 & \\
\hline & & & & & & & & & & & & & & & & & & & & & & & & & & & & 0 & & & & 0 & $0 \quad 0$ & \\
\hline 4. Rasl & & & & & & & & & & & & & & & & & & & & & & & & & & & $x$ & $x \mid$ & C & & 00 & 0 & 0 & 0 \\
\hline .0 & & & & & & & & & & & & & & & & & & & & & & & & & & & & Q & & 0 & 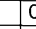 & & 0 & 0 \\
\hline . F & & & & & & & & & & & & & & & & & & & & & & & & & & & & & $\otimes$ & & 0,0 & 0 & 0 & 0 \\
\hline $\mathrm{N}$ & & & & & & & & & & & & & & & & & & & & & & & & & & & & & 0 & & 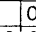 & & 0 & \\
\hline 8. Chyobi & & & & & & & & & & & & & & & & & & & & & & & & & & & & & & & 00 & & 0 & \\
\hline$F$ & & & & & & & & & & & & & & & & & & & & & & & & & & & & & & & $=0$ & & & 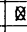 \\
\hline . $\mathrm{Ma}$ & & & & & & & & & & & & & & & & & & & & & & & & & & & & & & & & 0 & T & \\
\hline 1. $\mathrm{TC}$ & & & & & & & & & & & & & & & & & & & & & & & & & & & & & & & & & & 0 \\
\hline. $\mathrm{N}$ & & & & & & & & & & & & & & & & & & & & & & & & & & & & & & & & & $x$ & 0 \\
\hline . Me & & & & & & & & & & & & & & & & & & & & & & & & & & & & & & & & & & \\
\hline . Su & & & & & & & & & & & & & & & & & & & & & & & & & & & & & & & & & & \\
\hline 45. Noozu & & & & & & & & & & & & & & & & & & & & & & & & & & & & & & & & & & \\
\hline
\end{tabular}

troop. Thus. the same difference of dominance rank by ratio among identified individuals is much larger in the $A$ troop than in the $B$ troop. This reasoning further affirms the conclusion that the tendency, that the smaller the differences of dominance rank by ratio the higher the ratio of indefinite pairs was much more remarkable in the $B$ troop than in the A troop. The indefinite dominance pairs are not attributed to the youth of the tested individuals in the $B$ troop either, as the number of the individuals that were estimated 6 years old or less among tested individuals was 4 at maximum.

3. Seasonal change

Many cases of indefinite dominance 
relationships were observed in the study period in winter, the mating season. In this period, some of the oestrous females were observed to behave dominantly over non-oestrous females that were dominant over them when they were not oestrous. This might be one of the reasons which caused indefinite dominance relationships. Then a question arises whether indefinite dominance relationships occur in the nonmating season. Dominance tests were conducted in June, a non-mating season, 1974.

Pairs which showed reversal dominance relationships in June to those found in the winter period or showed nearly equal dominance relationships in the tests in June were selected as pairs of indefinite dominance relationships. The relative frequency distribution patterns of indefinite pairs to the differences of dominance rank by ratio are indicated for the upper class of the A troop and for the B troop (1-40th rank order by ratio) (Fig. 1-d, e). The characteristic feature of the appearance of indefinite pairs in regard to the differences of rank in the A troop did not change from the winter period to the June period. In the $B$ troop, the tendency of the smaller the difference of the dominace rank by ratio the more the indefinite dominance pairs weakened slightly. These results indicate that indefinite dominance relationships arise not only in winter but also in the other seasons.

Two remarkable factors which caused indefinite dominance relationships were observed in the course of the study. One is that of the oestrous females as stated already. The other is that of young mothers, carrying newborn babies on their abdominal parts, came into the central part of the troop and were tolerated by all of the troop and were tolerated by all of the troop members, even if they were low ranking and usually not permitted to stay in the central part of the troop. In the dominance tests between these individuals and others, reversal dominance relation ships in mothers to non-mothers were obtained in many pairs.

4. The blood relationships and the closeness of the differences of dominance rank by ratio.

Dominance relationships among adult females were reported to be definitely determined by the blood-relationships among them i.e. KaWAMURA's hypothesis (KAWAMURA, 1958; Koyama, 1967). Individuals that have blood-relationships are supposed to have close dominance rank by ratio on the basis of these reports. It is of much interest to know if this hypothsis still works in the Takasakiyama A troop despite the appearance of a high frequency of indefinite dominance pairs.

In order to estimate blood related individuals, cases of grooming among adult females were gathered on the supposition that individuals that showed especially high frequencies of grooming interactions had blood-relationships. 319 cases of grooming were obtained among 110 adult females that were listed on the dominance table of the A troop. The grooming frequency distribution pattern among each pair is indicated (Fig. 2). The number of possible pairs for 110 individuals are $5995\left({ }_{110} \mathrm{C}_{2}\right)$, and observed cases were 319 . 


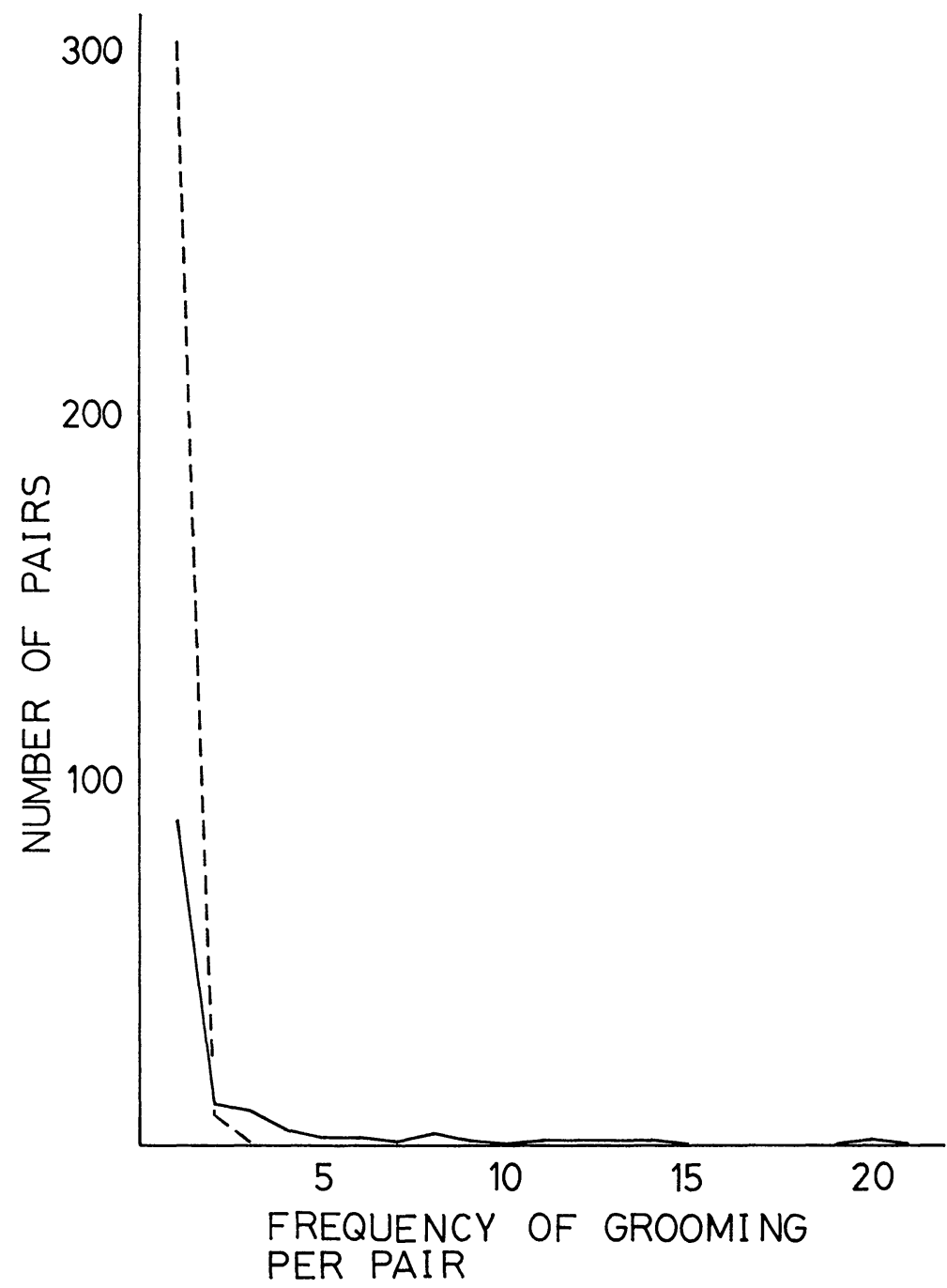

Fig. 2. Frequency distribution of numbers of grooming interactions per pair.

The solid line indicates the observed frequency. The broken line indicates the expected frequency.

Poisson distribution of the frequencies of grooming among each pair is indicated (Fig. 2). The probability of 3 times or more of grooming is 0.00003 , i.e. 0.179 times is expected for the observed frequency. Thus, pairs which showed cases of grooming for 3 times or more are expected to have strong affinitive relationships. Most of them might have bloodrelationships.

The differences of dominance rank by ratio between each groomer and groomee were investigated. The frequency distribution patterns of the differences of rank 


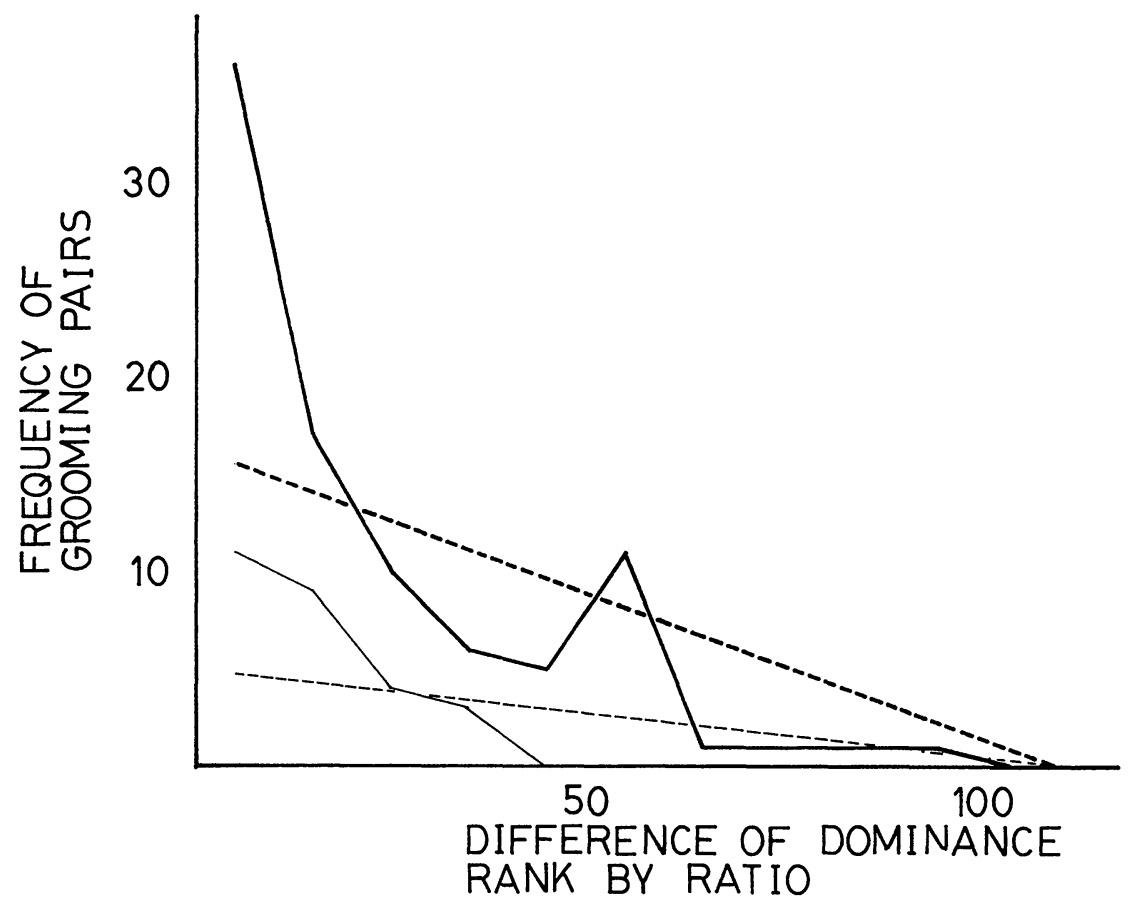

Fig. 3. Frequency distribution of numbers of grooming pairs to the difference rank by ratio.

The thick solid line indicates the observed frequency for grooming pairs, and the thick broken line indicates the expected frequency. The thin solid line indicates the observed frequency for the grooming pairs that conducted grooming over three times, and the thin broken line indicates the expected frequeny.

(the differences were grouped 1-10,11-20, related. This is further affirmed when $21-30, \cdots . .$.$) was obtained for the groom- the differences of dominance rank are$ ing pairs which conducted once or more, examined among more closely related inand 3 times or more, and were supposed dividuals that are expected to have bloodto have blood-relations (Fig. 3). The ran- relationships. Pairs which conducted 5 dom distribution pattern of the differences times or more of grooming interactions of rank was calculated (Appendix 2(b)) were examined (Table 4). Some of these (Fig. 3). Though the frequencies of gro- pairs were 20 or more of the differences oming pairs were much higher than the of dominance rank by ratio. Thus, bloodexpected value where the difference of related individuals can well be said to rank by ratio is small, the grooming pairs have tendency to have similar dominance were not confined to pairs of very small rank by ratio; nevertheless, many of the differences of rank, for example less than blood-related individuals have much great10 , as expected on the basis of $\mathrm{KAWA}^{-}$er differences of dominance rank by ratio MURA's hypothesis, when they were blood- than expected on the basis of the KAwA- 
Table 4. Differences of dominance rank order by ratio among monkeys that have frequent grooming relationships.

\begin{tabular}{|c|c|c|c|c|c|}
\hline \multicolumn{4}{|c|}{ pairs of interactions } & \multirow{2}{*}{$\begin{array}{c}\text { diff erences } \\
\text { of } \\
\text { rank }\end{array}$} & \multirow{2}{*}{$\begin{array}{c}\text { frequencies } \\
\text { of } \\
\text { grooming }\end{array}$} \\
\hline individuals & rank & individuals & rank & & \\
\hline Kesa & 31 & Kima & 56 & 25 & 33 \\
\hline Sumaat & 33 & Buresuto & 42 & 9 & 20 \\
\hline Egoni & 23 & Hasami & 57 & 34 & 14 \\
\hline Paru & 21 & Nyun & 3 & 18 & 13 \\
\hline Inokku & 73 & $\mathrm{Iku}$ & 79 & 6 & 12 \\
\hline Murasa & 26 & Tsuru & 38 & 12 & 11 \\
\hline Abura & 88 & Goma & 91 & 2 & 9 \\
\hline Shyuu & 14 & Pochi & 36 & 22 & 8 \\
\hline Ina & 95 & Tate & 94 & 1 & 8 \\
\hline Mushib & 30 & Giri & 46 & 16 & 8 \\
\hline Yoyo & 61 & Koi & 63 & 2 & 7 \\
\hline Saido & 97 & Nisan & 87 & 10 & 6 \\
\hline Nabe & 84 & Goma & 90 & 6 & 6 \\
\hline Yogo & 80 & Booingu & 98 & 18 & 5 \\
\hline Nabe & 84 & Abura & 88 & 4 & 5 \\
\hline
\end{tabular}

MURA's hypothesis. Thus the definite dominance rank system based on KAWAMURA's hypothesis is not expected to exist among adult females of the Takasakiyama A troop.

\section{DISCUSSION}

In the troops having extraordinary large population sizes such as the Takasakiyama $A$ and $B$ troops, a simple linear dominance rank order among troop members could not be found and many pairs showed indefinite doimnant-subordinate relationships. This contrasts with the definite, linear dominance rank order in ordinary sized troops reported up to now (Kawamura, 1958; Koyama, 1967). Moreover the character of the indefiniteness or vagueness of dominance relationships differed in the $A$ and in the $B$ troop, and the difference was definitely related to the difference of the population sizes of the A, about 1000, and the B troop, about 300 . In the $B$ troop, each of the pairs which showed indefinite dominance relationships was in most cases composed of members that had close dominance rank by ratio, whereas in the A troop definite dominance relationships were not established in many cases among adult females whose dominance rank by ratio were quite apart. This means that indefinite relationships in the A troop were not only caused by the smallness of the differences of dominance rank by ratio, that is the similarity of status, but was also caused by a quite different reason; inter-individual recognition among adult females may be quite impossible in the A troop having an extraordinary large population size whose adult females were estimated to be 308 monkeys (Sugiyama, OHsawa, Nishimura 
and MASUI, in press). Though inter-individual recognition among adult females might be possible in the troop having the kind of population size of the $B$ troop, 85 adult females estimated (Sugryama, OHSAWA, Nishimura and MASUi, in press), it is impossible to arrange in order all of the troop members by dominant-subordinate relationships; dominance rank order was not established among adult females. Thus, the different characteristics of the dominance relationships between the $A$ and the $B$ troop were related to the difference of the basic process of establishing dominance rank order.

On the other hand, one can have a question of whether the frequent occurrence of the indefinite dominance relationships which were observed only in the Takasakiyama $A$ and $B$ troop is to be attributed to the extraordinary large population sizes, or to the special characteristics of the local population of Takasakiyama troops. The answer to the question was obtained in another case of dominance tests conducted in the Takasakiya D troop (NISHIMURA, in press). The $\mathrm{D}$ troop budded out of the main A troop in 1967. Its population size was 74 , and females of 3.5 years or more were 26 monkeys. These females were fairly well linearly arranged in accordance with dominance rank order and pairs showing indefinite dominance relationships were very rare. The ratio of pairs of indefinite dominance relationships was $2.5 \%$ of the total pairs tested (Table 2). This ratio was very low in comparison with the ratio of the $A$ and the $B$ troop. Thus, the indefinite domi- nance relationships can be related to the largeness of the population sizes.

ITANI described that definite, clear-cut dominance rank order was not found among adult females of the Takasakiyama troop shortly after the beginning of the provisioning of the Takasakiyama troop (ITANI, 1954). He conducted dominance tests among 72 identified adult females of the Takasakiyama troop in 1955 (ITANI, personal communication). In order to examine his statement, 39 adult females whose dominance tests were conducted with over 20 individuals were selected from his dominance table and they were arranged in the order of dominance rank by ratio. Thus, a revised dominance table was obtained. The ratio of indefinite dominance pairs to the total pairs tested was $6 \%$ (Table 2). This ratio was close to that of the $B$ troop (Table 2). The relative frequency distribution of the difference of the dominance rank by ratio was obtained for the pairs of indefinite dominance relationships (Fig. 2). Pairs of indefinite dominance relationships were found among members whose differences of dominance rank by ratio were small, indicating the similar tendency in the B troop. The population size of the Takasakiyama troop in 1955 was estimated to be 358 (ITANI, 1964), being close to that of the B troop at this investigation. The dominance table from ITANI in 1955 can be reasonably compared with that in the $B$ troop, as the sampling ratio of the numbers of the adult females listed on the dominance table to the population size was 0.11 and was close to that in the $B$ 
troop in this report (Table 2). Thus, it can well be said that in troops having the population sizes about $300-360$, the similar tendency of dominance relationships will be obtained as the author observed in the B troop.

So far, it has been argued that extra large troop sizes result in the unstable dominant-subordinate relationships among adult females. However, the affect of provisionization on the unstable dominance relationships should also be considered.

When a troop is provisioned, food is placed in the feeding area, monkeys concentrate in the area and the frequency of inter-individual encounter is high. Moreover, each monkey must then decide if it should take or leave the food in front of others. In this situation dominance is recognized. Thus, the provisionization functions as a factor which strengthens dominant-subordinate relationships. The same agreement was made by ROWELL $(1966,1967)$ in a study comparing wild and caged baboon groups. Thus, the unstable dominance relationships in the Takasakiyama troops were not directly caused by provisionizing, but rather was the result of the gigantic population growth.

In this paper, it was indicated that indefinite or unstable dominance relationships among adult females appear in the Japanese monkey troop having extraordinary large population size. This result is str!kingly different from the previous reports (KAWAMURA, 1958; KoYAMA, 1967) stating that adult females of the Japanese monkeys had definite and linear dominance rank order. Further, it was stressed that the dominance rank order among adult females played an important role in maintaining integrity of the troop; the change of dominance relationships among adult females was a major factor which induced the division of the troop (KoYAMA, 1970). Following this view, the Takasakiyama troops with much indefinite dominance relationships was in an unstable state with the possibility of troop division in the study periods. On the contrary they seemed fairly stable and had extraordinary large population sizes. The division of the troop occurred two years after the study periods in the $A$ troop, and did not occur in the B troop. Thus, it is of much interest to know the mechanism of maintainig the integrity of the Takasakiyama troops and also to know the processes of the divisions of the troops observed up to now.

FURUYA analyzed factors which caused the divisions of the Japanese monkey troops and concluded that the division of the Japanese monkey troop generally occurred when the troop size reached up to $100-180$, and that there is an upper limit for the troop size of the Japanese monkey to maintain troop integrity (FURU YA, 1968). Though he raised several factors for the troop division, he did not fully analyze the relationship between the troop size and the dominance rank order among adult females at the time of the troop division. In this report, it is indicated that the indefiniteness of the dominace relationships among adult females 
increased quantitatively and qualitatively with the increase of the population size of the troop; dominance rank order became indefinite with the increase of the population size and its function of maintaining integrity of the troop loosened. This may be one of the major factors which leads a troop into a division.

It is of much interest that there seems to be a rough quantitative correlation between the occurrence of indefinite dominance relationships and the increase of population size. When the relation of the ratio of indefinite pairs to the pairs tested (X) and the population size of the troop $(\mathrm{N})$ is plotted on a graph, a rough equation is suggested to exist; $\mathrm{X}=\frac{0.2}{1000} \mathrm{~N}$ (Fig. 4). The reason for this equation to come into existence is not clear yet. When $25 \%$ is given as the ratio of adult females to the total population size of the Japanese monkey, the number of adult females in

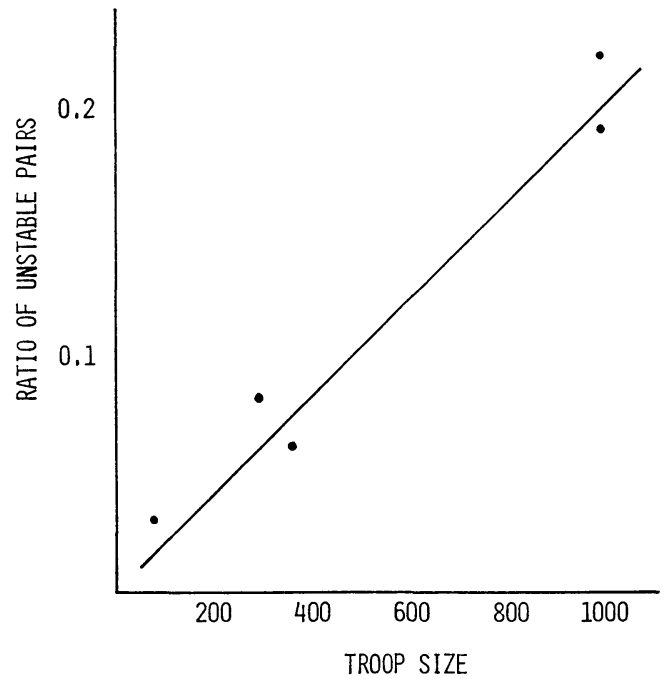

Fig. 4. The relation between the troop size and the ratio of pairs that have the unstable dominance relationships to total pairs.

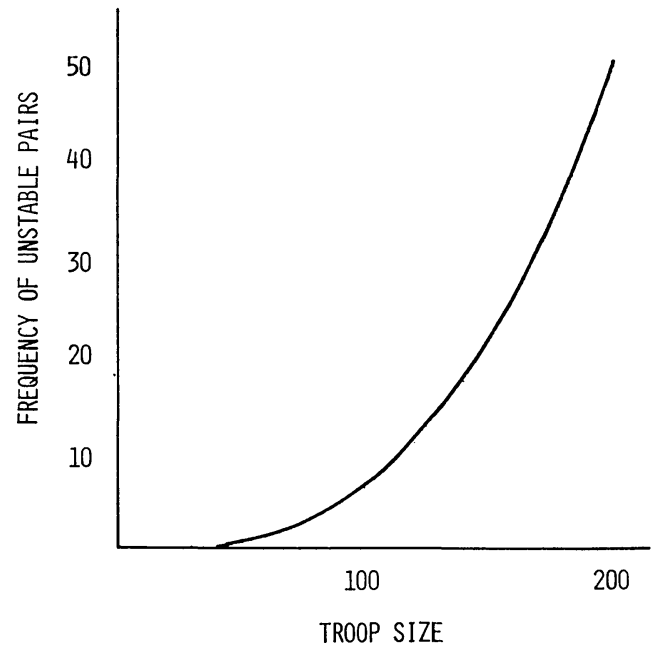

Fig. 5. The relation between the troop size and the frequency of unstable dominant-subordinate relationships among adult females.

a troop is $\frac{25}{100} \mathrm{~N}$ and indefinite pairs are $\frac{1}{2}\left(\frac{25}{100} \mathrm{~N}\right)^{2} \mathrm{X}=6.25 \times \mathrm{N}^{3} \times 10^{-6}($ Fig. 5). This equation indicates that the indefinite pairs increase rapidly after the population size exceeds 100 . This indicates that the function of dominance rank order in the mechanism of maintaining integrity of the troop decreases when the troop size increases over 100. Thus, the troop division is induced by this indefiniteness of dominance rank order reaching a critical point.

Several reasons may be given for why the Takasakiyama troops came to have such extraordinary large population sizes. First, much attention should be drawn to the fact that as the population increased, even to the extraordinary size, food was adequately given for the majority coming to the feeding area. Second, there is no space for the home range of a new branch troop, as the Takasakiyama mountain where monkey troops inhabit is an isolat- 
ed one and all of it is covered by the home ranges of three already existing troops. Third, the amount of social interactions among members of the troop was enhanced by making them gather in a small open feeding area despite the decrease of the interactions expected in each pair of individuals; the amount of interactions in each pair of individuals is expected to be in inverse proportion to the troop size, if the ratio of dispersion is kept the same.

On the other hand, it is of much interest that a troop can have such a large population size and the integrity of the troop is maintained if such conditions exist as mentioned already about the Takasakiyama troops.

As it is indicated that the dominance relationships based on the blood relationships (Kaw AmURA, 1958; Koy Ama, 1967) is not established in the Takasakiyama A troop and many individuals did not seem to recognize each other, it is doubtful in many cases that social interactions between a particular individuals are memorized and shaped into an inter-individual relationship and further shaped into a string of the social network. Thus, the mechanisms which work in maintaining integrity of the Takasakiyama A troop are not merely based on the inter-individual relationships, such as dominance rank order, but on some other mechanisms which are not based on inter-individual relationships.

The differences of the mechanisms which sustain integrity of the troops in ordinary sized troops and the Takasakiyama A troop reveals itself in examining the processes of the divisions of troops; the differences were based on the differences of the roles of inter-individual relationships. The different features of the divisions of the troops are revealed in the following: in the Takasakiyama troops (Sugryama, 1960 ; Kano, 1964 ; Nishimura, 1973) and in troops whose population sizes were under 200, such as the Arashiyama troop (Koyama, 1970) and the Gagyusan troop (Furuya, 1968, 1969). In each of the three divisions of the Takasakiyama major troop, monkeys gradually gathered just around or in the peripheral part of the troop and they were formed into a group and gradually separated from the main troop. In the cases of the Arashiyama and the Gagyusan troops, the troops were divided suddenly into two troops; unstable inter-individual relationships accompanying the population increase caused many contradictions in the social structures and they suddenly broke out into troop divisions. The troops were divided by the contradictions within the troops. On the other hand, in the Takasakiyama troop, the population size had already exceeded over 200 because of many factors already mentioned. And inter-individual relationships did not have much meaning in such groups. Then, inter-individual relationships did not lead the troop into strifliling conflicts among troop members nor troop division by conflicts. But, they loosened integrity of the troop, and a portion of the peripheral part of the troop parted gradually from the central part and formed a branch troop. 
On the other hand, the affect of provisionization on the troop fission is considered. Generally speaking, the food supply determines the upper limit of the numbers of animals that can survive in a given habitat. In this sense, the provisionization has an influence on the size of the troop.

In the provisionization of monkeys abundant food is given and they tend to live in high densities. Thus, the provisionization is a factor which induce a large troop size and is not the direct factor for the troop fission. FURUYA (1969) investigated five troop fissions in the Gagyusan troop and stated that the amount of food was not directly related to the troop fissions, but a food shortage which continues for a long time may have some affect on the troop fission. The Takasakiyama troops experienced high growth rates during the study periods, and a food shortage was not observed. Thus, an adequate provisionization has no direct influence on troop fission except through the population growth which result in communication and sociological difficulties.

It can be said that communication and sociological factors which regulate the troop size of the Japanese monkeys were analyzed in this report by diminishing the influence of a population limiting factor, food amount, under artificial feeding conditions. The major concern of this report is to know how the extra large troops, the Takasakiyama troops, can be integrated socially and communicatively.

The results of this report are as follows:
(1) when the troop size increases such that dominance relationships or inter-individual relationships cannot be stable or definite, then troop fission usually occurs and (2) when "artificial" food is given abundantly, the troop size continues to increase as in the cases of the Takasakiyama troops, and the troop tend to behave superficially in a way not much different from an ordinary sized troops.

This indicates that the integrity of the troop has two aspects: the first aspect is the aggregation of the monkeys centralized by some mechanisms, and the second is the strong organizing functions of interindividual relationships such as bloodrelationships and the dominance rank order. The Takasakiyama A troop showed that a troop can have an entity without the latter. This indicate the importance of the former aspect over the latter for the integration of a troop.

In the former aspect, the structure must mainly depend on some sets of behavioral patterns, because the social relationships play a minor role. The more important sets of behavioral patterns are (1) the coordination of troop movements (2) the control of aggressions-aggressions must be repressed by some behavior patterns, because social relationships do not function to repress them-(3) the indifference to the non-related individuals.

Troop coordination occurs as follows; monkeys of the troop seemed to pay much attention to the movements of the males of the leader class. When they returned to the forest from the feeding area, central females seemed to coordinate their 
movements to those of the leaders and left the feeding area followed by peripheral members. The attention by female members to the leaders in the troop movements was experimentally analyed by Kurokawa (1975) and the same result was obtained. Therefor, it can be argued that this behavioral pattern is based on the attention behavior (CHANCE, 1967) of the followers (i.e. females and their young) to the adult males, and is not based on a complicated social hierarchy.

Although many sets of behavioral patterns exist to control aggression, the most obvious is the avoidance mechanism (MORI, 1975). That is, monkeys behave so as not to approach too closely to others, there by diminishing aggressions.

The behavior pattern, the indifference to others, is found in the fact that monkeys tend not engage in aggression when it occurs among other troop members. For example, when aggression begins among females of the Takasakiyama A troop, it usually does not spread among adult females and seemed to be confined to related mothers and children. This is in sharp contrast to the aggression observed in ordinary sized troops where aggression sometimes spreads to many unrelated adult females. This set of behavioral pattern has newly developed in the Takasakiyama A troop.

Because the above sets of behavioral patterns facilitate the entity of a troop and maintain the extra large population size of a troop, these behavioral patterns must be the essential characters of the species, Macaca fuscata. According to these sets of behavioral patterns, the social structure is based on the existence of the leaders and on the control of the aggressions between troop members. Other structures are not prerequisite for the troop integration.

Though leaders literally seem to be authoritative, their authority really based on a simple behavioral pattern of attention. Attention structure and avoidance mechanism and other phylogenetic traits may also be important in human interaction. The indifference to others has newly developed in the Takasakiyama A troop. These results in the Japanese monkeys may suggest that the development of a large population size in human societies probably did not require a complicated authoritative structure, and was a rather easy process.

The major factor determining the troop size of primates is phylogenetic traits (STRUHSAKER, 1969; ItANI, 1972), although the environmental factors are considered to be important by others (CROOK and Cartlan, 1966). Therefor, the above sets of behavioral patterns may be the phylogenetic traits of the Japanese monkeys, and these traits ensure the possibility of the troop enlargement. Thus, one of the most important aspects of troop size are phylogenetic traits which are compiled in sets of behavioral patterns relating to troop integration. This aspect may be farther important in the study of human population.

The population sizes of the human groups have been analyzed in relation to environmental and cultural factors (BIRD- 
SELL, 1968). Fairly constant numbers of group sizes, 25 and 500 , were obtained for a local group and a dialectical group respectively among hunters and gatherers, in spite of a wide variety of environmental and cultural conditions. These numbers have often be called magic numbers. The constancy of the human local population size may be due to the phylogenetic traits of the human. This agrees with the assumption that among primates the most important factor controlling troop size is phylogeny.

From the above point of view, the study of behavioral patterns which are useful in the study of non-human primate population must also be adopted in the study of human population. Farther investigations, including those of apes, might, therefore, also find some benefit in studying mechanisms which integrate human populations.

\section{ACKNOWLEDGEMENT}

I would like to thank the Keepers of the Takasakiyama Wild Zoo Park for their aid, especially Mr. Koichi KAWAI who helped me to identify individuals and also newly identified many individuals together with me and checked errors in individual identification. I wish to thank Dr. Junichiro ITANI of Kyoto University who gave me suggestions and offered unpublished data. I am grateful to Dr. Masao KawaI of Kyoto University for his critical reading of this manuscript.

\section{APPENDIX}

1. The ratio of dominance for each indi- vidual is determined by the number of the individuals that each individual was dominant over. This was divided by the number of individuals with which it had definite dominance, dominant or subordinate, relationships. All of the tested individuals, 120 monkeys, were arranged according to the ratio of dominance from the highest to the lowest. These 120 individuals were divided into 3 classes, upper, middle and lower, each consisting of 40 individuals. The ratio of dominance is newly calculated within each class and individuals are rearranged within each class. Next, individuals of the lower half of the upper class, 20 individuals, were put together with those of the upper half of the middle class, and then the ratio of dominance is calculated within this group of individuals. The upper half of the re-calculated group is put back to the upper class and the lower to the middle class. In this process 4 individuals of each of the upper and the middle class were exchanged. Likewise, two individuals of each of the middle and lower classes were exchanged. The data of dominance tests was scarce among individuals of the lower class. Individuals listed on the dominance table were only those whose dominance tests were conducted over five individuals within the lower class. Two individuals disappeared in the June study period and were excluded from the dominance tables. Then the upper, middle and lower class consisted of 39,39 and 32 individuals respectively and the dominance tables were made within each class by arranging individuals according 
to the ratio of dominance within each class.

2. (a) The frequency distribution of pairs is calculated for each difference of dominance rank by ratio. Those that have the same difference of dominance rank by ratio are listed the same distance from the diagonal line of the dominance table. If the total individuals on the table is given to be $\mathrm{N}$, those pairs that have difference of $\mathrm{i}$ dominance rank, are $\mathrm{N}-\mathrm{i}$. Thus, the probability of the difference of $\mathrm{i}$ dominance rank is $(\mathrm{N}-\mathrm{i}) / \sum_{\mathrm{i}=1}^{\mathrm{N}}(\mathrm{N}-\mathrm{i})=$ $(\mathrm{N}-\mathrm{i}) / \frac{\mathrm{N}}{2}(\mathrm{~N}-1)$. The difference of dominance rank by ratio is grouped by 3 ranks, $(1 \sim 3),(4 \sim 6),(7 \sim 9), \cdots \cdots(\{3(i-1)$ $+1\} \sim 3 i) \cdots \cdots\left(i=1,2,3, \cdots \cdots, \frac{N-1}{3}\right)$. Then, the probability of the difference of $\{3(\mathrm{i}-1)$ $+1\} \sim 3 \mathrm{i}$ dominace rank is $(3 \mathrm{~N}-9 \mathrm{i}+3) / \frac{1}{2}$ $\mathrm{N}(\mathrm{N}-1)$. The probability is calculated by giving $\mathrm{N}=40$, though the individuals on the dominance table were 39 (Fig. 2).

(b) The difference of dominance rank by ratio is grouped by ten, $(1 \sim 10),(11 \sim$ $20), \cdots \cdots(\{10(\mathrm{i}-1)+1\} \sim 10 \mathrm{i}), \cdots \cdots(\mathrm{i}=1,2$, $\left.3, \cdots \cdots \frac{\mathrm{N}-1}{10}\right)$. The probability for $\mathrm{i}-$ th difference of dominance rank is $\frac{10}{2}(2 \mathrm{~N}-20 \mathrm{i}$ $+9) / \frac{1}{2} \mathrm{~N}(\mathrm{~N}-1)$. The probability is calculated by giving $\mathrm{N}=110$ (Fig. 4).

\section{REFERENSES}

Birdsell, J.B., 1968: Some predictions for the Pleistocene based on equilibrium systems among recent hunter-gatherers. In; Man the Hunter. R. B. LEE and I. DEvore (eds.), Aldine Publishing Company, Chicago.

ChANCE, M. R. A., 1967: Attention structure as the basis of primate rank orders. Man, 2: 503-518.
Crook, J.H. and J.S. GARTLAN, 1966: Evolution of primate societies. Nature Lond., 210 : 1200-1203.

FURUYA, Y., 1968: On the fission of troops of Japanese monkeys, I; Five fissions and social changes between 1955 and 1966 in the Gagyusan troop. Primates, 9(4): 323-350. 1969: On the fission of troops of Japanese monkeys, II; General view of troop fission of Japanese monkeys. Primates, 10(1): $1-46$.

ITANI, J., 1954: Takasakiyama no Saru (Japanese monkeys in Takasakiyama). In; Nihon Dobutsuki II. K. IMANISHI (ed.), Kobunsha, Tokyo. (in Japanese)

, 1972: Reichorui No Shakaikozo(Primate Social Structures). pp.161. Kyoritsu Shuppan K.K., Tokyo. (in Japanese), K. TOKUDA, Y. FURUYA, K. Kano, and Y. SHIN, 1963: The social construction of natural troops of Japanese monkeys in Takasakiyama. Primates, 4(3): 1-42.

KANO, K., 1964: Takasakiyama nihonzaru shizengun no dai 2 ji bunretsu ni tsuite (On the second division of the natural troop of Japanese monkeys in Takasakiyama). In; Takasakiyama no Yaseinihonzaru (Wild Japanese Monkeys in Takasakiyama). Keisoshobo, Tokyo. (in Japanese)

KAWAI, M. 1958: On the rank system in a natural group of Japanese monkeys (I), (II). Primates, 1(2): 111-148.

KAWAMURA, S., 1958: Matriarchal social ranks in the Minoo-B troop -A study of the rank system of Japanese monkeys. Primates, 1(2): 149-156.

KoyAmA, N, 1967: On dominance rank and kinship of a wild Japanese monkey troop in Arashiyama. Primates, 8(3): 189-216. 1970: Changes in dominance rank and division of a wild Japanese monkey troop in Arashiyama. Primates, 11(4): 335390.

KUROKAWA, T., 1975: An experimental field study of cohesion in Katsuyama group of Japanese monkeys. In; Contemporary Primatology. S. Karger, Basel. 
MORI, A., 1975: Intratroop spacing mechanism of the wild Japanese monkeys of the Koshima troop. In; Contemporary Primatology. S. Karger, Basel.

Nishimura, A., 1973: The third fission of a Japanese monkey group at Takasakiyama. In; Behavioral Regulators of Behavior in Primates. C. R. Carpenter (ed.), Associated University Press, New Jersey. , in press: Group fissions of Japanese monkeys at Takasakiyama-from third to sixth fissions. In; Population Dynamics of Japanese Monkeys at TakasakiyamaReports of the Investigation; 1971-1976. (in Japanese)

Rowell, T.E., 1966: Forest living baboons in Uganda. J. Zoology, 149: 344-364.
1967: A quantitative comparison of the behaviour of a wild and a caged baboon group. Animal Behaviour, 15: 499-509.

STRUHSAKER, T. T., 1969: Correlates of ecology and social organization among African cercopithecines. Folia Primatologica, 11: 80118.

SugryamA, Y., 1960: On the division of natural troop of Japanese monkeys at Takasakiyama. Primates, 2(2): 109-148.

, H. OHsawa, A. Nishimura and K. MASUI, in press: Population dynamics of Japanese monkeys at Takasakiyama by periodical censuses. In; Population Dynamics of Japanese Monkeys at Takasakiyama-Reports of the Investigation; 1971-1976. (in Japanese) (Received January 29, 1977)

特に大きなポピュレーション・サイズを持つ

ニホンザル餌付け群の社会構造

\section{森明 雄 \\ 京都大学 霊長類研究所}

餌付けされた二ホンザルの群れ，高崎山A及びB群は，それぞれ約 1000 頭，300頭と群れサイズは非常に大 きい。A群の群れサイズは自然群の10倍以上の大きさである。 $\mathrm{A}$ ， B 群のおとなのメス間で順位テストを行な い，おとなのメス間の順位関係を調べた。このテストで優劣関係が不明確であったり不安定である個体関係が 多数見出され，また直線的順位関係が得られなかったので, テストでの各個体に対する勝率を計算し,勝率の大 きい方から小さい方へ配列した勝率順位を各個体に与えた。優劣の不明確な個体関係の出現の特徵を調べたと ころ，優劣の不明確な個体関係が $\mathrm{B}$ 群では勝率順位のより近い個体間で出現し，A群では勝率順位のかなり離 れた個体間にも出現した。B群における優劣の不明確な個体関係は, 順位落差の小ささに起因するすのであり, より群れサイズの大きな A群では, 優劣の不明確な個体関係は個体数の増大に伴なって生じた個体間の相互認 知の不明確さに起因するものと推定された。A群では血縁関係のある個体間でも勝率順位はかなり離れている ものが見られたが，乙のととは他の群れサイズの小さい群れで見られるメス間の血縁関係に基づく整然とした 順位関係が成立していないととを示した。非常に大きな群れサイズを持つ高崎山の群れの社会構造は，通常の サイズの群れで明らかにされてきた個体関係の積み重ねだけでは解明できないてとが示された。A群及び B 群

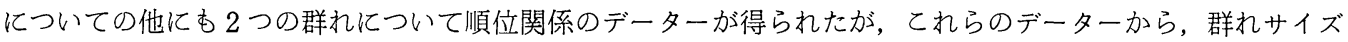
の増大に伴ないおとなのメス間の優劣の不安定な個体関係が増加することが示され, 特汇群れサイズが 100 頭 を越えると急速に不安定な優劣関係が多数出現するようになるととが示された。これらのととから，てれまで に報告されたニホンザルの群れの分裂過程における 2 つの異なった様相は, 群れサイズの相異によるととが明 らかにされた。 